\title{
LUCERNARIA DISCOIDEA, A NEW SPECIES FROM THE CHANNEL ISLANDS
}

\author{
By N. B. Eales, D.Sc. \\ University of Reading
}

(Text-figs. I-3)

While collecting on the Zostera beds at Grève d'Azette, Jersey, on August 23 I937 Mr R. B. Pike found fourteen specimens of an unknown lucernarian. These Zostera beds, made famous by the work of Mr J. Hornell, are now greatly impoverished, and at extreme low tide during the spring tide period only a few scattered patches of the weed remain. Hornell reported Haliclystus octoradiatus from this area, and it was while searching for it that the present species was found.

The general form of the lucernarian is typical (Fig. I), but more delicate than that of $L$. campanulata. When alive, the colour was greenish yellow, with numerous scattered, pale yellow, opaque spots all over the umbrella, and a few cerulean blue spots between the genital bands not far from the mouth. The yellow and blue colour rapidly disappeared in formalin. The specimens vary in size from 5 to $20 \mathrm{~mm}$. high, and from 3 to I5 $\mathrm{mm}$. across the bell. The basal disk is distinct and is broader than the peduncle, which is rather long and slender, and expands gradually into the umbrella. Of the fourteen speci-

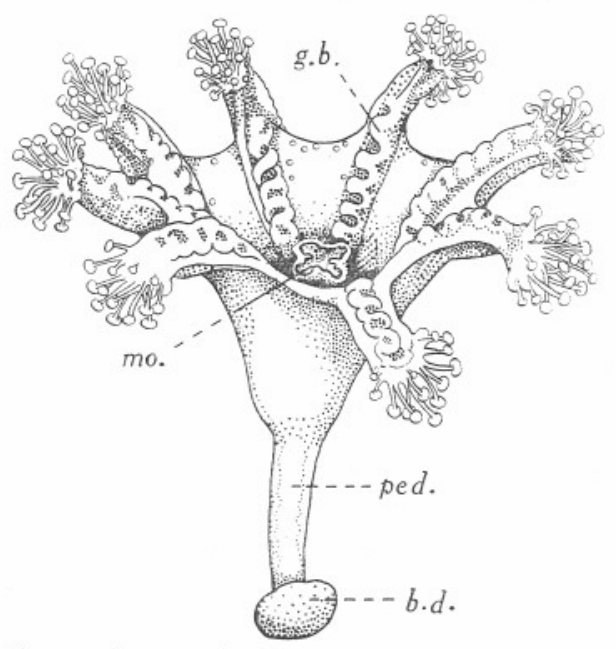

Fig. I. Lucernaria discoidea n.sp.; an individual of medium size in lateral view. $\times 5 . b . d$. basal disk; g.b. genital band; mo. mouth; ped. peduncle.

mens, one has twelve arms, twelve have eight arms, and one has seven arms, the odd arm in the last specimen being formed by the fusion of two arms. The normal number can therefore be taken as eight. In a fully expanded specimen the length of the free arm is about one-third of the radius of the umbrella, and the tentacles which crown the arm are the distinguishing feature of the species. In all other species of both Lucernaria and Haliclystus which I have been able to trace, the tentacles are rounded and button-like (capitate) at the tips, the nematocysts being confined to this area. In the species here described the fully formed tentacle has a flat disk at its apex, although young 
tentacles show that the discoid type is derived from the normal rounded one and the disk can be contracted to form a thick "cake". The number of tentacles in a bunch rarely exceeds twenty-five and is usually fewer (Fig. 2). Though all are slender, the size and shape vary, and three kinds can be distinguished:

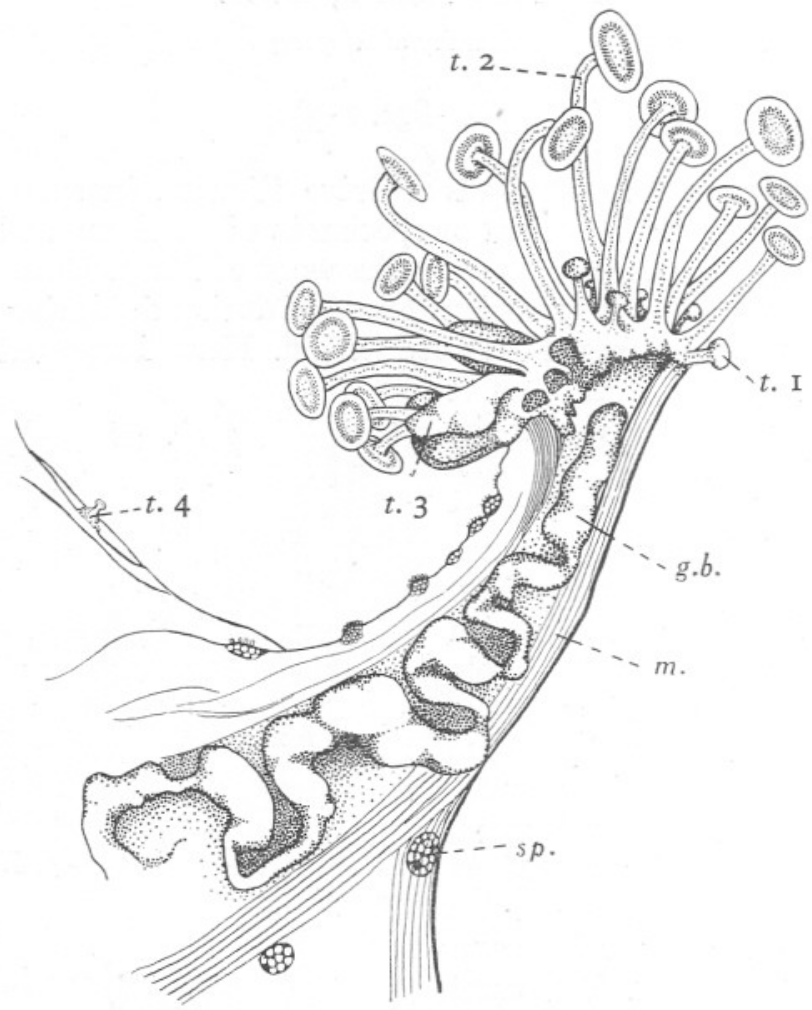

Fig. 2. The arm of $L$. discoidea n.sp. from the oral side. Its apex is twisted to the right to expose the aboral glandular tentacles. $\times 25$. g.b. genital band; $m$. muscle; $s p$. opaque spot on umbrella; $t$. I, capitate tentacle; $t .2$, discoid tentacle; $t .3$, glandular discoid tentacle; $t .4$, vestigial per- or interradial tentacle.

(a) On the oral side of the arm are from four to six short capitate tentacles (Fig. 2, $t$. I).

(b) On the extremity of the arm are situated about ten or twelve long slender tentacles, with disk-shaped heads set at right angles to the centrally placed stalk, somewhat like the podia of an Echinus (Fig. 2, t. 2).

(c) On the aboral side of the summit of the arm are from three to five tentacles with discoid heads, and rather short stalks expanded greatly on the aboral side of the base to form glandular adhesive organs. A bulbous prolongation of each swollen area is contained within the arm (Fig. 2, t. 3). 
The cruciform mouth with frilled lips projects on a short manubrium from the centre of the umbrella, and is held in place by four perradial strips fastened to the umbrella between the adradially situated genital bands, as the latter diverge towards the arms. The interradial areas being free from such attachment are usually more widely expanded, so that the genital bands naturally fall into four groups of two each, although symmetry is regained on the umbrella margin. (Cf. L. quadricornis, where the arms are grouped in twos.) The genital bands are of characteristic shape, being sinuous and swollen, but continuous. They extend as far as the base of the tentacles, and appear to possess one aperture for each band near the tip. The gastric filaments are unbranched, the stalk is one-chambered, but four bands run downwards as continuations of the taenioles. On the inner surface of the disk these bands broaden out, are visible externally, and have the shape of a four-rayed clover-leaf.
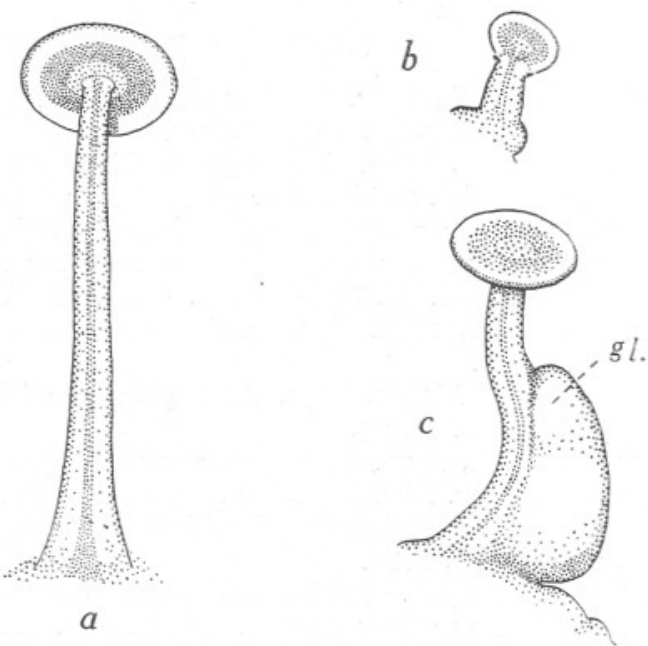

Young specimens exhibit two Fig. 3. Three types of tentacle from the arm of $L$. points of difference from adults. The tentacles tend to resemble the ordinary capitate type, and discoidea n.sp. $\times 60$. $a$, tall discoid; $b$, short capitate; $c$, short glandular discoid: $g l$. glandular base of tentacle.

there is in some a single capitate tentacle on the umbrella edge in the centre of each bay between the arms. In older specimens these isolated perradial and interradial tentacles become reduced in size and may either disappear or persist in one or more of the bays. Elmhirst (I922) noted similar tentacles in L. quadricornis.

Although $L$. discoidea is here called a new species, it was discovered over eighty years ago by H. Milne Edwards at Langrune, east of Cherbourg, and accurately figured by him in the Disciples' Edition of Cuvier's Règne Animal, I847. He found orange and greenish specimens, and gave a coloured figure of the former. He noted both the knob-shaped and disk-shaped tentacles, the opaque spots on the umbrella, the sinuous nature of the genital bands, the simple gastric filaments, and the swollen basal expansions of the peduncle supports. He did not see, however, the adhesive pads on the outer tentacles, or the attachment of the mouth angles. His specimens did not possess the blue spots. At the time two species of lucernarian were known, viz. Müller's L. auricula and L. quadricornis, the former a Haliclystus and the latter a Lucernaria. Milne Edwards called his specimens L. auricula, an obvious error 
in the light of present-day knowledge, since his specimens had no colletocystophores and Müller's had. Consequently a specific name is required for it, and $L$. discoidea is suggested, because of the peculiarity of the tentacles.

Specimens have been deposited in the British Museum of Natural History, and I should like to thank Dr A. K. Totton for his assistance with the literature, and $\mathrm{Mr}$ Pike for drawings of the animal.

\section{REFERENCES}

Browne, E. T., I9Io. Coelentera. V. Medusae. Rept. Nat. Antarct. Exped. Nat. Hist., Vol. 5, pp. I-62, Pl. I-7.

Carlgren, O., I930. Die Lucernariden. Further Zool. Results Swedish Antarct. Exped., Vol. II, No. 4, p. I8.

— I935. Über eine neue Südafrikanische Lucernariide, Depastromorpha africana n.gen., n.sp., nebst Bemerkungen über den Bau und die Systematik dieser Tiergruppe. K. Svenska Vet. Akad. Handl., Ser. III, Vol. I5, No. I, 24 pp.

Clark, H. J., I878. Lucernariae and their Allies. Washington, Smithsonian Institution.

Edwards, H. Milne, I847. Le Règne Animal (Cuvier, Disciples' Edition, I838-49), p. III and Pl. 63.

Elmhirst, R., I922. Notes on Lucernaria quadricornis Müller, and related Species. Ann. Mag. Nat. Hist., Vol. Io, 9th ser. pp. $22 \mathrm{I}-4$.

Haeckel, E., I879. System der Medusen. Jena, pp. I-672.

Müller, O. F., I806. Zoologica Danica. Havniae, p. 35, Pl. I52.

UCHIDA, T., I929. Studies on the Stauromedusae and Cubomedusae, with special reference to their metamorphosis. Fap. Fourn. Zool. Tokyo, Vol. II, pp. 103-89.

UCHIDA, T. \& HANAOKA, K., I933. On the morphology of a stalked medusa, Thaumatoscyphus distinctus Kishinouye. Fourn. Fac. Sci. Hokkaido Imp. Univ., Ser. 6, Zool. Vol. 2, pp. 135-53.

_ 1934. Anatomy of two stalked medusae with remarks on the distribution of the Stauromedusae in Japan. Fourn. Fac. Sci. Hokkaido Imp. Univ., Ser. 6, Zool. Vol. 2, pp. $21 \mathrm{I}-38$. 